\title{
EXTRADIGITAL GLOMUS TUMOUR IN SCAPULAR REGION
}

\author{
Taosef Syed ${ }^{1}$, Rijesh Pottangadi², Sadanandan A. N³, U. Jayaprakash ${ }^{4}$
}

${ }_{1}^{1}$ Senior Resident, Department of Orthopaedics, Malabar Medical College Hospital and Research Centre, Kozhikode. ${ }^{2}$ Assistant Professor, Department of Orthopaedics, Malabar Medical College Hospital and Research Centre, Kozhikode. ${ }^{3}$ Associate Professor, Department of Orthopaedics, Malabar Medical College Hospital and Research Centre, Kozhikode. ${ }^{4}$ Professor and HOD, Department of Orthopaedics, Malabar Medical College Hospital and Research Centre, Kozhikode.

HOW TO CITE THIS ARTICLE: Syed T, Pottangadi R, Sadanandan AN, et al. Extradigital glomus tumour in scapular region. J. Evolution Med. Dent. Sci. 2017;6(50):3872-3874, DOI: 10.14260/Jemds/2017/836

\section{PRESENTATION OF CASE}

A 76-year-old male patient had presented with history of backache for the last 15 years with features of pain even with mild touch (such as while wearing shirt). He had this complaint more than 15 years back and was operated twice; at tertiary care hospital on one occasion and secondary care hospital on another occasion at one-year interval. He later had persistent pain similar in character to what he had before surgery and used to take OTC analgesics occasionally for pain relief and had considered it 'incurable and his fate.' The treatment details were not available with the patient and could not be traced. On examination, there was an oblique linear surgical scar over inferior angle of right scapula, around $3 \mathrm{~cm}$ in length with faint reddish macule present over inferior and lateral aspect (at distal end of scar), which was tender and hypersensitive to touch and cold. Rest of the scar was nontender. The surrounding skin appeared normal with no induration or collection. He had no other site with similar hypersensitive lesion. Examination of Spine, Shoulder and Scapula were within normal limits.

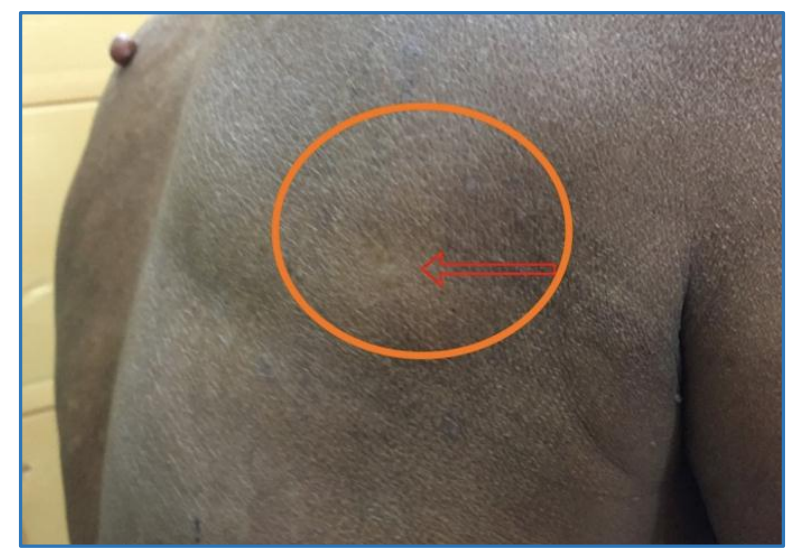

Figure 1. Clinical Picture of Patient's Back- Right Scapular Region, Circle Enclosing the Oblique Surgical Scar with Arrow Pointing to the Macule

\section{DIFFERENTIAL DIAGNOSIS}

At such presentation, differential diagnoses, which were considered were glomus tumour, neuroma, haemangioma or a hamartoma.

Financial or Other, Competing Interest: None.

Submission 16-04-2017, Peer Review 10-06-2017,

Acceptance 16-06-2017, Published 22-06-2017.

Corresponding Author:

Dr. Rijesh Pottangadi,

\#34/733, 'Pottangadi',

PO Civil Station,

Kozhikode-673020, Kerala.

E-mail: drrijesh@gmail.com

DOI: $10.14260 /$ jemds/2017/836

\section{(c) (1) $(9)$}

\section{CLINICAL DIAGNOSIS}

Ultrasound examination of the local part, though initially was thought as not feasible due to extreme hypersensitivity was ordered after discussing with patient. This revealed a welldefined cystic lesion measuring $7 \mathrm{~mm} \times 4 \mathrm{~mm}$ with thick echogenic content noted in subcutaneous plane of right scapular region. No significant vascularity was however noted. MRI was not done, as patient could not afford.

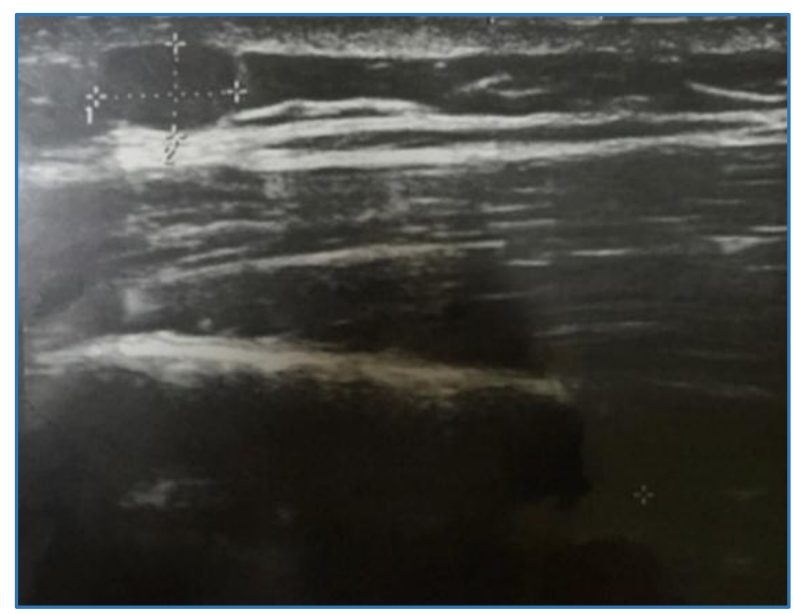

Figure 2. Ultrasound showing the Lesion- 7 x $4 \mathrm{~mm}$, just Deep to Skin, in Left Upper Quadrant of Picture

He was planned for excision biopsy of the lesion under general anaesthesia. After intubation, patient was placed in semi-prone position with right shoulder on top and pillow under the chest. After sterile draping, a $4 \mathrm{~cm}$ long elliptical incision was placed to include the scar and the macule with at least $2-5 \mathrm{~mm}$ of skin margin around the lesion and scar. Incision was extended to subcutaneous tissue, deep enough to include the lesion in toto and skin with the lesion excised. The skin was sutured after haemostasis. The well-defined pale brown lesion measuring around $5 \mathrm{~mm} \times 5 \mathrm{~mm}$ was confirmed to have been removed completely and was bisected to assess macroscopically and send in toto to Pathology Department for histopathological examination. The patient made an uneventful recovery and sutures were removed at 2 weeks' time.

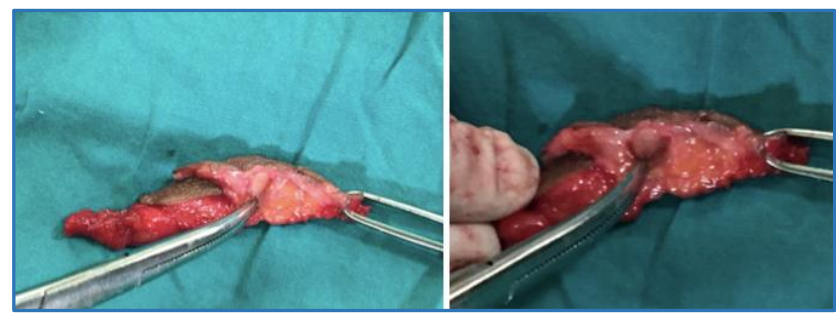

Figure 3. Excised Specimen, Bisected 


\section{PATHOLOGICAL DISCUSSION}

Histopathologic section showed skin with the dermis showing a well-circumscribed lesion composed of tight convolutes of mainly thin-walled and occasionally thick-walled, dilated, congested blood vessels of varying sizes surrounded by collars of glomus cells. These cells were rounded with sharply punched-out, rounded nucleus and a clear to amphophilic cytoplasm. Periphery of the lesion showed a rim of collagen containing blood vessels. There was no evidence of atypia, mitosis or necrosis. Adjacent dermis appeared unremarkable. Findings suggested Classic (sporadic) Glomus tumour. Post-op 9 months patient is asymptomatic.

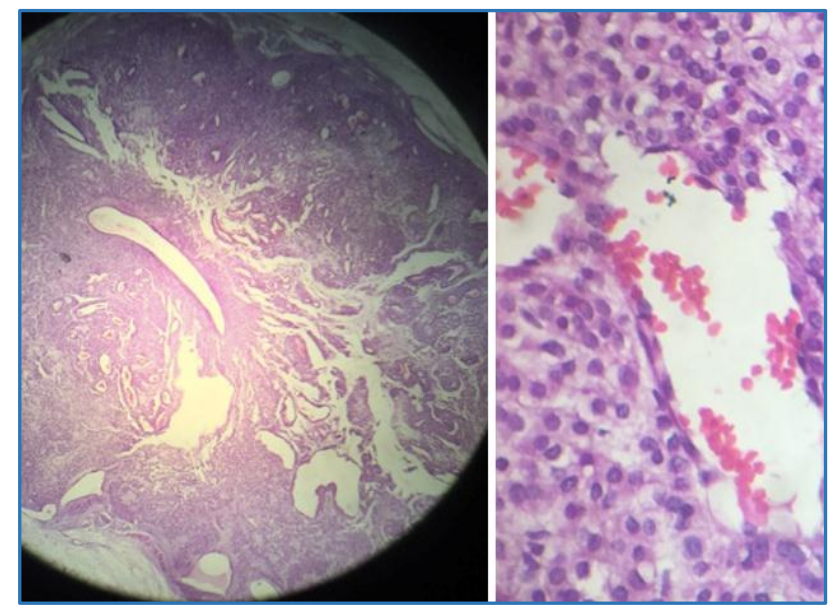

Figure 4. Low Power and High Power Microscopic View

\section{DISCUSSION OF MANAGEMENT}

Glomus tumour is a benign neoplasm, malignant cases are extremely rare.[1] It arises from Glomus body in subcutaneous tissue. Most common site is the subungual area,[2] affecting more females than males $[\mathrm{M}<\mathrm{F}=1: 2] .[3]$ Extradigital presentations are rare and often misdiagnosed, and they occur with more frequency among males, $(\mathrm{M}>\mathrm{F}) .{ }^{[4]}$ Here, we have reported an extradigital Glomus tumour in scapular region.

Glomus tumour was first described by Wood[5] and was later explained in detail by Masson.[6] Glomus body is Neuromyoarterial canal system, which is responsible for blood flow to skin and thermoregulation.[7] Glomus tumour usually presents with the triad of- i) High temperature, ii) Sensitivity, iii) Pain and localised tenderness. ${ }^{[8,9,10]}$

WHO has subcategorised Glomus Tumour into Three Types:

\section{Solid Type}

Most common variant with scarce vasculature and minimal muscle component.

\section{Angiomatous Type}

Ganglioma, predominantly vascular.

\section{Glomangiomyoma}

Predominantly vascular and smooth muscle components.

Most common location is digits of hand. Extradigital sites are rare and have been reported in shoulder, scapular region, ${ }^{[11]}$ elbow, ${ }^{[12,13,14]}$ forearm, ${ }^{[15,16]}$ wrist, ${ }^{[17]}$ palm, thigh,[1,18,19] knee,[20,21,22] foot,[23,24] toes,[23,25] stomach,[26] colon,[26] larynx,[27] posteroinferior lung,,28] mediastinum,[29] intramuscular, intravascular,[30] intraneural, cervix, penis and bone, $[31,32,33,34,35,36]$ arm, [36] buttock, ${ }^{[36]}$ leg, ${ }^{[37]}$ ankle, ${ }^{[36]}$ back,, ${ }^{[36]}$ nose, ${ }^{[36]}$ cheek,[36] ear lobe[ ${ }^{[36]}$ and trachea.[36]

Extradigital glomus tumours are difficult to diagnose as they do not present with classical triad. Pain is due to local hyperplasia of neuroangiomatous tissue, resulting in a tumour which causes pain either by mechanical or thermal stimulus. There is increase in intracapsular pressure due to contraction of myofilaments of glomus cell and this increase in pressure causes pain, which is carried by unmyelinated nerve fibres. Differential diagnoses for glomus tumour should be kept in mind which are neuromas, haemangiopericytomas, angioleiomyomas, haemangiomas and hamartomas of cutaneous adnexa. There is 12 to $33 \%$ of recurrence of solitary tumours.[37] MRI is a valuable imaging modality in occult suspected lesion, where ultrasonographic scan is not helpful.[38] Malignancy is to be considered if the tumour size is more than $2 \mathrm{~cm}$ or located deep or on histological evidence of atypical mitotic figures with moderate-to-high nuclear grades, more than or equal to 5 mitotic figures per HPF.[39]

\section{FINAL DIAGNOSIS}

The final diagnosis in this patient can thus be said to be Extradigital classic (sporadic) Glomus tumour in scapular region. Proper history, careful examination, appropriate investigation and early diagnosis and treatment are required for a good functional outcome. Patient with extradigital glomus tumour of scapular region can be confused with scapular, shoulder or spinal pathology. So, in any case of localised painful lesion with hypersensitivity and local raise of temperature, glomus tumour should be considered as differential and should be confirmed by excision biopsy.

\section{REFERENCES}

[1] Beksaç K, Dogan L, Bozdogan N, et al. Extradigital glomus tumor of thigh. Case Reports in Surgery Article ID 638283, 2015;2015: p. 3 . http://dx.doi.org/10.1155/2015/638283.

[2] SS Kale, VK Rao, ML Bentz. Glomus tumor of the index finger. J Craniofac Surg 2006;17(4):801-4.

[3] Maxwell GP, Curtis RM, Wilgis EF. Multiple digital glomus tumors. J Hand Surg (Am) 1979;4(4):363-7.

[4] Tsuneyoshi M, Enjoji M. Glomus tumor. A clinicopathologic and electron microscopic study. Cancer 1982;50(8):1601-7.

[5] W Wood. On painful subcutaneous tubercle. Edin Med J 1812;8:283-91.

[6] Masson P. Le glomos neuromyoarterial des regions tactile et les tumeurs. Lyon Chir 1924;21:257-80.

[7] Ricardo Gonçalves, Lopes A, Julio C, et al. Knee glomangioma: a rare location for a glomus tumor: a case report. Rare Tumors 2014;6(4):5588. www.researchgate.net/publication/270656654.

[8] Schiefer TK, Parker WL, Anakwenze OA, et al. Extra digital glomus tumors: a 20-year experience. Mayo Clin Proc 2006;81(10):1337-44.

[9] Waseem M, Jari S, Paton RW. Glomus tumor, a rare cause of knee pain: a case report. The Knee 2002;9(2):161-3.

[10] van Geertruyden J, Lorea P, Goldschmidt D, et al. Glomus tumors of the hand. A retrospective study of 51 cases. J Hand Surg (Br) 1996;21(2):257-60. 
[11] Venugopal PR. Extradigital glomus tumor-a rare cause for undiagnosed chronic pain in unusual sites. Indian J Surg 2015;77(Suppl 3):910-12.

[12] Zreik N, Talbot C, Peach C. Glomus tumour of the elbow: a case of mistaken identity. Shoulder Elbow 2014;6(2):134-6.

[13] Burnier M, Erhard L. Glomus tumor of volar elbow capsule. Case report. Chir Main 2014;33(1):67-70.

[14] Anley C, Vrettos B, Roche S, et al. Glomus tumour of the elbow: a case report and review of the literature. Shoulder Elbow 2014;6(1):60-2.

[15] Jarmundowicz W, Haftek J. Glomangiomas of atypical location. Neurol Neurochir Pol 1984;18(4):339-43.

[16] Lee SK, Song DG, Choy WS. Intravascular glomus tumor of the forearm causing chronic pain and focal tenderness. Case Reports in Orthopedics Article ID 619490, 2014;2014: p. 4. http://dx.doi.org/10.1155/2014/619490.

[17] Balaram AK, Hsu AR, Rapp TB, et al. Large solitary glomus tumor of the wrist involving the radial artery. Am J Orthop (Belle Mead NJ) 2014;43(12):56770.

[18] So SY, Kim BM, Lee SY, et al. Glomus tumor causing anterior thigh pain: a case report. Korean J Pain 2014;27(2):174-7.

[19] Amillo S, Arriola FJ, Muñoz G. Extra digital glomus tumour causing thigh pain: a case report. J Bone Joint Surg Br 1997;79(1):104-6.

[20] El Hyaoui H, Messoudi A, Rafai $M$, et al. Unusual localization of glomus tumor of the knee. Joint Bone Spine 2016;83(2):213-5.

[21] Maxey ML, Houghton CC, Mastriani KS, et al. Large prepatellar glomangioma: a case report. Int J Surg Case Rep 2015;14:80-4.

[22] Mentzel T, Dei Tos AP, Sapi Z, et al. Myopericytoma of skin and soft tissues: clinicopathologic and immunohistochemical study of 54 cases. Am J Surg Pathol 2006;30(1):104-13.

[23] Mohindra M, Sambandam B, Gautam VK, et al. A rare case of glomus tumor of the great toe. An analysis of behavior at this rare site. American Journal of Surgical Pathology 2001;Vol 25(1):1-12.

[24] Valero J, Gallart J, Gonzalez D, et al. Giant glomus tumor and neuroma in the fifth ray-a case report. J Am Podiatr Med Assoc 2016;106(2):151-4.

[25] Pater TJ, Marks RM. Glomus tumor of the hallux: case presentation and review of the literature. Foot \& Ankle International 2004;25(6):434- 7.

[26] Miettinen M, Paal E, Lasota J, et al. Gastrointestinal glomus tumors: a clinicopathologic, immunohistochemical, and molecular genetic study of 32 cases. American Journal of Surgical Pathology 2002;26(3):301-11.
[27] Aslam N, Qazi ZUS, Ahmad AH, et al. Malignant glomus tumour of larynx: first case report and literature review. The Journal of Laryngology and Otology 2012;126(7):743-6.

[28] Ariizumi Y, Koizumi H, Hoshikawa M, et al. A primary pulmonary glomus tumor: a case report and review of the literature: case report. Case Reports in Pathology Article ID 782304, 2012;2012: p. 6. http://dx.doi.org/10.1155/2012/782304.

[29] De Chiara A, Apice G, Mori S, et al. Malignant glomus tumour: a case report and review of literature. Sarcoma 2003;7(2):87-91.

[30] Parthenis DG, Paraskevas KI, Staramos DN, et al. Glomangioma of the upper limb associated with hypoplastic-dysplastic superficial venous system. Int Angiol 2004;23(4):79-81.

[31] Lau YY, Ho PC, Tse WL, et al. Intraosseous glomus tumor treated by toe-to-finger transfer: case report. J Hand Surg Am 2009;34(4):710-4.

[32] Weiser JA, Nord KM, Grossman ME. Glomus tumor masquerading for 22 years as osteoarthritis of the hip. Cutis 2008;81(4):339-42.

[33] Wanik M, Majchrzak H, Bierzyńska-Macyszyn G, et al. A case of lumbar glomeruloma. Neurol Neurochir Pol 1993;27(1):127-9.

[34] Simmons T], Bassler T], Schwinn CP, et al. Case report 749: primary glomus tumor of bone. Skeletal Radiol 1992;21(6):407-9.

[35] Lo WW, Solti-Bohman LG, Lambert PR. High-resolution CT in the evaluation of glomus tumors of the temporal bone. Radiology 1984;150(3):737-42.

[36] Schopp JG, Sra KK, Wilkerson MG. Glomangioma: a case report and review of the literature. Cutis 2009; 83(1):24-7.

[37] Lee DW, Yang JH, Chang S, et al. Clinical and pathological characteristics of extradigital and digital tumours: a retrospective comparative study. J Eur Acad Dermatol Venereol 2011;25(12):1392-7.

[38] Matloub HS, Muoneke VN, Prevel CD, et al. Glomus tumor imaging: use of MRI for localization of occult lesions. J Hand Surg Am 1992;17(3):472-5.

[39] Folpe AL, Fanburg-Smith JC, Miettinen M, et al. Atypical and malignant glomus tumors: analysis of 52 cases, with a proposal for the reclassification of glomus tumors. Am J Surg Pathol 2001;25(1):1-12. 